\title{
Trade Union Membership and Earnings in Kenyan Manufacturing Firms*
}

\author{
by \\ Damiano Kulundu Manda \\ Department of Economics \\ University of Nairobi \\ Arne Bigsten \\ Department of Economics \\ University of Gothenburg \\ and \\ Germano Mwabu \\ Department of Economics \\ University of Nairobi \\ Working Papers in Economics no 50 \\ May 2001 \\ Department of Economics \\ Göteborg University
}

\begin{abstract}
This paper analyses the effect of trade unions on earnings in Kenyan manufacturing using a switching regression model, which takes into account endogeneity of union status of workers. In contrast to earlier studies of the Kenyan labour market, which indicate that the union effect on wages is negative, our results show a strong positive trade union effect. We also show that it is workers with relatively weak position in the labour market that joins the union.
\end{abstract}

Keywords: Unions, wages, manufacturing, Kenya

JEL-classification: J5

* We would particularly like to thank Henry Ohlsson for very useful suggestions. 


\section{Introduction}

In Kenya, unionisation is found in the manufacturing, trade, transport sectors, large-scale agriculture and teaching service. The trade unions' main objectives are to improve the welfare of its members by negotiating high earnings for its members, bettering their conditions of service, and by increasing job tenure. Given these attractive objectives, one would expect a majority of workers to be trade union members. However, only a third of the formal sector workers have joined trade unions. In the manufacturing sector, 40 percent of the workers and 47 percent of the production workers are union members. Despite the relatively stronger unionisation in Kenyan manufacturing, our knowledge of how trade unions affect earnings in the sector is still sparse. This paper analyses the effect of trade unions on earnings using data from the manufacturing sector.

Conflicting empirical evidence exists concerning the influence of trade unions on wages. Most studies in this area have been based on the experience of developed countries and very few attempts have been made to estimate the relationship for developing countries, especially in Sub-Saharan Africa. For instance, a study by Hansen (1997) for Sweden finds the effect of trade unions on wages to be negative for male workers and positive for female workers. Schultz and Mwabu (1998) find a negative union effect on wages for certain categories of white workers in South Africa, while the effect was positive for black workers. In Kenya, the study by Johnson (1971) finds that union wages were 30 percent higher than non-union wages in private industries and 11 percent in the public sector. However, Johnson fails to consider in his analysis factors such as firm size, which might be correlated with union membership. In another study, House and Rempel (1976) using OLS estimation techniques find the coefficient of unionisation on wages to be -0.41 and not statistically significant. However, they do not include such determinants as education and experience in their analysis. In another Kenyan study, Manda (1997) finds that trade unions wages were about 22 percent lower than for non-union. Thus, there is need for more and better empirical analysis of the effect of trade unions on earnings.

The three Kenyan studies have two common weaknesses. To start with, some of the studies base their analysis on wages and not earnings (i.e., wages plus allowances and other benefits). If union workers receive more allowances than non-union workers, the analysis of the effect of 
trade unions based on wages and earnings is bound to be different. The second shortcoming of the earlier Kenyan studies is that they estimate a single equation model without taking into account the endogeneity of the union membership variable, which will bias the estimates of the effect of trade union membership on earnings. Lastly, the studies do not deal with the selectivity problem, which may arise when the choice to join trade unions is not completely random. We will show that when an appropriate model is applied, the results change dramatically.

The questions addressed in this study include the following. What is the effect of trade unions on earnings? Are there any major differences in the characteristics of union and non-union workers? Do union workers receive more allowances than non-union workers? Before addressing these questions and others to be raised later in the text, we briefly review the situation of trade unions and related institutions in Kenya (see Bigsten, 1984 and Manda, 1997 for details).

The paper is organised as follows. Section 2 briefly reviews the development of the trade union movement in Kenya. Section 3 begins with the formulation of the model, followed by a description of the data set. Section 4 presents the empirical results of the analysis, while Section 5 summarises and concludes the paper.

\section{The Trade Union Movement}

The first attempt at organised trade unions in Kenya was in 1919, when European and Indian workers organised staff associations (Singh, 1969, and Lubembe, 1968). During the colonial period, the authorities tried to suppress union activities through intimidation, harassment and arrest of union officials. The declaration of the state of emergency in the early 1950s made it more difficult for unions to operate, as union officials were detained, while others joined the freedom fighters' Mau Mau movement. However, towards the late 1950s, trade unions became increasingly important and better established and the basic structure of the present trade unions in Kenya was almost complete in 1960 and 1961, when unions catering for agricultural workers were formed (Bigsten, 1984). 
After Independence, however, the new government sought central control of the trade union movement much in the same way as the colonial regime had done and attempts by the unions to maintain their independence were overpowered by the government. In fact many rights of the workers conceded by the colonial government had been circumscribed, if not eliminated by Kenya’s first African government by the early 1970s (Collier and Lal, 1986).

Trade unions in Kenya are generally financially weak and are occasionally faced with internal leadership struggles arising from personal, tribal and other differences. Their main source of finance is membership fees, which are not enough, for example, to pay strikers to sustain a strike. In addition, their ability to strike is limited in several ways, which include central control of the labour movement activities by the government, legislation and the threat of deregistration of the trade unions.

One of the avenues of state control over trade union activities was through the appointment by the head of government of the top officials of Central Organisation of Trade Unions (COTU) from a list of poll winners. The second means of state control over trade union activities was through a series of "tripartite agreements" between workers, government and employers, in which employers pledge to increase employment by a certain percentage if workers refrain from demanding wage increments over a given period. The third channel is the power given to the registrar of societies to de-register trade unions, which do not "behave" (e.g. in 1980, the state de-registered the civil servants' union and the University staff union). Finally, a series of Trade Dispute Acts in 1964 and 1965 and the amendments of 1969 and 1971, progressively limited the unions right to strike.

The main effect of all these measures, together with the existence of many job seekers willing to take the jobs of the strikers if they refuse to go back to their jobs, has been to reduce the number of strikes and man-days lost. For instance, in 1962, the year just before Independence, there were 285 strikes, resulting in 0.7 million man-days lost. The number of strikes declined to 110 in 1986 and further to 92 in 1990 and to 42 in 1996. The man-days lost declined to 0.2 million in 1986, and to between 0.02 and 0.05 million in the 1990s (see Manda, 1997). 
Trade union activities are restricted by legislation and constrained by lack of finance. The limits on the trade unions' ability to strike means that collective bargaining is the main mechanisms through which trade unions can influence the level of earnings in Kenya. However, the unions may not have enough resources to hire negotiators with skills and ability to match the full-time negotiators for the employers. Therefore one might presume that the unions have a limited influence on wages. Nevertheless, given that union leaders are dependent on the members for financial and personal support, they press harder for workers demands even if they are unpopular to the government and sometimes gains have been made (Sandbrook, 1975)

\section{Model and Data}

\subsection{Model and Estimation Strategy}

an appropriate model for estimating union membership premium and union status choice is the switching regression model with endogenous switching (see, e.g., Lee, 1978; Willis and Rosen, 1979; Lanfranchi, Ohlsson and Skalli, 2000). This model provides a unified framework for testing selectivity and pooling, taking account of endogeneity between union status and earnings.

There are several potential problems related to the empirical estimation of the trade unionearnings effect. The first problem arises from model misspecification. The key issue here is: is it possible to pool data for union and non-union workers? To fix ideas, let the earnings equations be represented by equations (1a) and (1b).

$$
\begin{aligned}
& \mathrm{W}_{\mathrm{ui}}=\beta_{1}{ }^{\prime} \mathrm{X}_{1 \mathrm{i}}+\mathrm{u}_{1 \mathrm{i}} \\
& \mathrm{W}_{\mathrm{ni}}=\beta_{2}{ }^{\prime} \mathrm{X}_{2 \mathrm{i}}+\mathrm{u}_{2 \mathrm{i}}
\end{aligned}
$$

where $\mathrm{W}_{\mathrm{ui}}$ are $\log$ hourly earnings for union workers and $\mathrm{W}_{\mathrm{ni}}$ are $\log$ hourly earnings for nonunion workers and vector $\mathrm{X}$ includes the standard explanatory variables in the earnings equation, while $\mathrm{u}_{1}$ and $\mathrm{u}_{2}$ are error terms. If the returns to each characteristic are the same for all workers, we can pool the data and estimate a single earnings equation. However, if returns $(\beta s)$ 
differ, we must allow union and non-union workers to have different earnings equations.

The second problem is selectivity. This may arise if the union membership choice is not completely random. Suppose the choice is determined by equation (2) below.

$$
\begin{aligned}
& I_{i}^{*}=\alpha_{0}+\delta_{\mathrm{i}} \mathrm{Z}_{\mathrm{i}}+\gamma\left(\mathrm{W}_{\mathrm{ui}^{*}-}-\mathrm{W}_{\mathrm{ni}} *\right)+\mathrm{v}_{\mathrm{i}} \\
& I_{i}=1 \text { if } I_{1}^{*} \geq 0 \text { and } 0 \text { otherwise }
\end{aligned}
$$

where $I_{1} *$ is a latent variable determining whether the discrete outcome $I_{i}$ occurs and the exogenous variables are assumed to be independent of the error term vi. Only the outcomes, $I_{i}$ are observed. The term $\mathrm{W}_{\text {ui* }}-\mathrm{W}_{\text {ni* }}$ captures the union premium. Some, but not all the variables in $\mathrm{X}$ from equation (1) appear in $\mathrm{Z}$ in equation (2), which is estimated by ML (maximum likelihood) methods.

The error terms in equations 1 and 2 may be correlated giving rise to selectivity bias. Let $\sigma_{\mathrm{u} 1, \mathrm{v}}$ and $\sigma_{\mathrm{u} 2, \mathrm{v}}$ represent the covariances between the choice equation, $\mathrm{v}$, and the error terms in the two earnings equations $\mathrm{u}_{1}$ and $\mathrm{u}_{2}$. If there is a positive selection into trade union that is, covariance $\sigma_{\mathrm{u} 1, \mathrm{v}}$ is positive it means that the covariance $\sigma_{\mathrm{u} 2, \mathrm{v}}$ is negative. To take into account selectivity problem we use reduced form union status choice equation, which takes the form:

$$
I^{*}=\delta \mathrm{Z}+\gamma\left(\beta_{\mathrm{u}}-\beta_{\mathrm{n}}\right) \mathrm{X}+\gamma\left(\mathrm{u}_{1}-\mathrm{u}_{2}\right)+\mathrm{v}
$$

Assuming uniform values for $\beta s$ and a common $u$, expression (3) can be re-written in compact form as $I^{*}=\gamma^{Z}+\mathbf{v}$. Following Maddala (1983) we can compute conditional expected earnings using equations ( $4 \mathrm{a}$ and $4 \mathrm{~b})$.

$$
\begin{aligned}
& \mathrm{E}\left(\mathrm{W}_{\mathrm{u}} \mid \mathrm{U}=1\right)=\left(\beta_{\mathrm{u}} \mathrm{X}+\sigma_{\mathrm{u} 1, \mathrm{v}}\right) /[\Phi(\gamma \check{\mathrm{Z}})] \\
& \mathrm{E}\left(\mathrm{W}_{\mathrm{n}} \mid \mathrm{U}=0\right)=\beta_{\mathrm{n}} \mathrm{X}+\sigma_{\mathrm{u} 2, \mathrm{v} \mathrm{v}}[(\phi(\gamma \check{\mathrm{Z}}) /(1-\Phi(\gamma \check{\mathrm{Z}}))]
\end{aligned}
$$

where $\phi(\gamma \check{Z})$ and $\Phi(\gamma \check{Z})$ are the density function and the distribution functions of the standard normal evaluated at $\gamma \check{Z}$. Including $+\sigma_{\mathrm{u} 1, \mathrm{v}}, \phi / \Phi$ and $-\sigma_{\mathrm{u} 2, \mathrm{v}} \phi /(1-\Phi)$ when estimating the respective 
earnings equations will control for selectivity and yield estimates of the covariances. Estimating the earnings equations (1a) and (1b) without controlling for selectivity will give biased estimates if the error covariances are nonzero. The most likely effect is that the difference between union and non-union earnings will be underestimated.

The earnings equations (1a) and (1b) and the choice equation (2) constitute a switching regression model with endogenous switching and can be used to estimate union premia and the effect of union premia on union status. The model provides a unified procedure for testing for selectivity and for pooling data on union and non-union employees. The model can be estimated using full information maximum likelihood. Alternatively the structural probit can be used in several steps as follows.

- Estimate the reduced form union choice equation (3) using ML methods to get $\gamma$ and then compute $\phi(\gamma \check{Z})$ and $\Phi(\gamma \check{Z})$;

- Estimate the selection model corresponding to (4a) and (4b) using two a step procedure and compute $\left(\mathrm{W}_{\text {ui* }}-\mathrm{W}_{\mathrm{ni}^{*}}\right)$ for each worker;

- Estimate the structural form choice equation (2) using ML.

If $\sigma_{\mathrm{u} 1, \mathrm{v}}$ and $\sigma_{\mathrm{u} 2, \mathrm{v}}$ are statistically significant in the earnings equations, we know that correction for sample selection was indeed needed. Pooling can be tested using two approaches as follows. Maddala (1983) suggests an empirical specification where the expected earnings function is:

$$
\mathrm{E}(\mathrm{W})=\beta_{\mathrm{n}} \mathrm{X}+\left(\beta_{\mathrm{u}}-\beta_{\mathrm{n}}\right) X \Phi(\gamma \check{\mathrm{Z}})+\left(\sigma_{\mathrm{u} 1, \mathrm{v}}-\sigma_{\mathrm{u} 2, \mathrm{v}}\right) \phi(\gamma \check{\mathrm{Z}})
$$

Equation (5) can be estimated using a two-step procedure. This model is known as the treatment effects model in which $\beta$ and $X$ are vectors and $\beta_{u}=\beta_{n}$ for all $X$ except the constant term (see Lanfranchi, Ohlsson, and Skalli 2000). The model can be viewed as the restricted version of the selectivity controlled earnings equation, in the sense that all the slope coefficients of the explanatory variables are the same for union and non-union members. In that case, equation (5) collapses to 


$$
\mathrm{E}(\mathrm{W})=\beta \mathrm{X}+\alpha \Phi(\gamma \check{Z})+\left(\sigma_{\mathrm{u} 1, \mathrm{v}}-\sigma_{\mathrm{u} 2, \mathrm{v}}\right) \phi(\gamma \check{Z})
$$

where $\alpha$ equals the difference in $\beta$-coefficients for the constant. This differential captures the effect of trade unions on earnings. Pooling for the whole model can be tested by an F-test of the treatment effects model vs the separate earnings equations. If pooling for the whole model is rejected, we can the test for pooling by estimating equation (5). The impacts of the variables specified in the equations will differ between union earnings and non-union earnings if the estimated coefficients $\left(\beta_{u}-\beta_{n}\right)$ are statistically significant.

\subsection{Data}

The data used in our study comes from the Regional Programme on Enterprise Development (RPED) survey of the manufacturing sector in Kenya. The data set is a three-year panel survey of more than 200 manufacturing sector firms carried out by a team of researchers from the Departments of Economics of the University of Gothenburg and the University of Nairobi in collaboration with the Kenya Association of Manufacturers in the years 1993 to 1995. Whereas the data on firms is a panel (with a few replacements in 1994 and 1995), data on individuals is not a panel. The survey covered firms in four manufacturing sub-sectors (food, textile, wood and metal) in four major urban centres in Kenya (Nairobi, Mombasa, Nakuru and Eldoret). The four sub-sectors comprise about 72 percent of the manufacturing sector and, therefore, the data provides a comprehensive picture of the manufacturing sector.

The labour market sections of the survey provide information on both firm and individual characteristics. The information on firms was elicited from representatives of each firm and includes total number of firm employees, total wage bills, profits, firm ownership, proportion of firm employees in trade unions among other things. This provides more accurate information on, for instance, firm size than would be the case when individuals provide such information. The information on individuals was obtained through interviews, with at most ten employees randomly chosen from a list of workers of each firm. The employees interviewed provided information on, for example, earnings, education level, previous experience, tenure, union status, age, sex, and hours of work. 
The variables included in the analysis are defined as follows. The dependent variables are union status for the probit equation and the natural logarithm of hourly earnings for the earnings function. The hourly earnings are estimated by dividing the monthly earnings by the total number of hours of work in a month (i.e. hours of work in a week multiplied by 4.3 weeks in a month). The independent variables include dummy variables for union status (predicted), location, sub-sectors, education, on-the-job training, general training, occupation, sex, and surveys periods (waves 1 through 3). On-the-job training can be taken to be firm specific, while general training is an equivalent of vocational training. The time dummy variables are included to capture the time effects on wage rates that arise due to changes in macroeconomic factors and in policies. Other independent variables include a measure of firm size (measured in terms of the number of employees in a firm), age of the employee and its square, tenure, and previous experience which we use as an identifier for the probit equation.

Since trade unions in Kenya are concentrated in the formal manufacturing sector, our analysis makes use of data on workers and firms in the formal manufacturing sector. About 90 percent of the observations in our data set are for formal manufacturing sector workers.

\section{Results}

\subsection{Descriptive Statistics}

The means and standard deviations of the variables used in the analysis are shown in the Appendix. The difference between hourly earnings and hourly wages for all workers in the formal manufacturing sector is about Kshs. 4 (US\$ $1=$ Kshs 57 in 1995). This shows that on average, allowances and other benefits form about 18 percent of the total earnings. The variation in hourly earnings is also higher than in the hourly wages. A large proportion of the respondents have primary and secondary education with only a few having university education. Thus, individuals with at least primary education formed a majority (about $85 \%$ ) of the workforce in the formal manufacturing sector (from here henceforth manufacturing sector) in the period 1993-95. This reflects the impact of the rapid expansion of the education system on 
the labour force (Manda, 1997). The average tenure for workers in the manufacturing sector is about 8 years. Also about 70 percent of the firms in our data are located in Nairobi. Most of the respondents (86 percent) are males indicating that only $14 \%$ of the sample respondents are females. This reflects the domination of the manufacturing sector by male workers.

About 39 percent of the workers in the manufacturing sector are union members. This is not far different from the national estimate of about a third of the workers. However, it shows that manufacturing sector is relatively more unionised than other sectors of the economy. Membership of trade unions is not compulsory in Kenya. The question is whether there is any distinct group of workers who join the union. We attempt to answer this question using information in Table 1.

Table 1: Means of Selected Variables by Union Status -- Formal Manufacturing Sector

\begin{tabular}{lccll}
\hline Variables & \multicolumn{2}{c}{ All workers } & & \multicolumn{2}{c}{ Production workers } \\
\cline { 2 - 5 } Hourly Earnings & Union & Nonunion & Union & Nonunion \\
Hourly Wages & 20.23 & 25.24 & 18.47 & 18.26 \\
Weekly hours of work & 16.08 & 21.44 & 14.60 & 16.90 \\
Age & 45.61 & 46.58 & 45.63 & 46.82 \\
Primary Dummy & 36.00 & 33.32 & 35.73 & 32.80 \\
Secondary Dummy & 0.46 & 0.38 & 0.49 & 0.49 \\
University Dummy & 0.34 & 0.45 & 0.28 & 0.31 \\
On-the-job training & 0.01 & 0.03 & 0.00 & 0.01 \\
General training & 0.27 & 0.23 & 0.28 & 0.22 \\
Production & 0.14 & 0.20 & 0.13 & 0.15 \\
Firm size (workers) & 0.73 & 0.54 & - & - \\
Tenure (years) & 195.00 & 135.90 & 133.6 & 84.41 \\
Previous experience (years) & 9.82 & 7.14 & 9.6 & 6.70 \\
Located in Nairobi & 5.45 & 5.34 & 5.22 & 5.34 \\
Located in Mombasa & 0.75 & 0.62 & 0.77 & 0.57 \\
Located in Nakuru & 0.11 & 0.14 & 0.10 & 0.17 \\
Located in Eldoret & 0.08 & 0.11 & 0.08 & 0.13 \\
Male & 0.06 & 0.12 & 0.05 & 0.13 \\
Food sector & 0.89 & 0.84 & 0.89 & 0.89 \\
Wood sector & 0.23 & 0.19 & 0.25 & 0.20 \\
Textile sector & 0.25 & 0.24 & 0.24 & 0.27 \\
Metal sector & 0.26 & 0.27 & 0.24 & 0.20 \\
Union density & 0.26 & 0.28 & 0.27 & 0.33 \\
Total Number of observations & 69.31 & 34.76 & 70.10 & 29.7 \\
\hline & 1077 & 1664 & 788 & 895 \\
\hline
\end{tabular}


As shown in Table 1 columns 1 and 2, the hourly earnings and wages are higher for non-union workers than for union workers. The same columns show that the difference between hourly earnings and hourly wages are higher for union workers than non-union workers. This indicates that union workers receive higher allowances and other benefits than non-union workers. In fact union production workers in the formal sector receive higher earnings than non-union production workers yet their hourly wages are lower than for the non-union workers. This implies that part of the reasons why workers join the union is to boost their earnings by receiving higher allowances and other benefits than for non-union workers.

The weekly hours of work for union workers are lower than for non-union workers. This shows that apart from joining unions to get better earnings, workers also join trade unions in order to push for better working conditions in terms of fewer hours of work. The table also shows that on average the age of union workers is about 36 years compared with 33 for non-union workers. It is possible that the older workers are less educated and probably join the union to secure job security. Job insecurity may arise from the fact that the younger and better educated individuals may be preferred to the older workers by the employers. It is also likely that many of the young workers being highly educated work in occupations such as management, which do not allow one to join trade unions or they join firms where trade unions are not available. While the proportion of union workers with primary education is higher than the proportion of non-union workers with primary education, the proportion of non-union workers with secondary and university education is lower than the proportion of union workers with the same level of education. It is also shown that tenure is higher for union than non-union workers (see Table 1).

As shown on the table, about 14 percent of the union workers and 20 percent of the non-union workers have general training. On the other hand, 73 percent of production workers are union workers compared with 56 percent non-union production workers. This shows that production workers are a dominant group of the union workers. The vast majority of both union and nonunion workers in the manufacturing sector is male. Also most union workers seem to work in larger firms than non-union workers. Lastly, union workers are in firms that are more unionised than those for non-union workers. This suggests that the union density of a firm may have some influence on union status of the workers. 


\subsection{Estimation Results}

As a first step in the analysis we start by estimating the reduced form probit (equation 3 ) for union membership choice. The estimated marginal effects and t-values are reported in columns 2 and 3 of Table 2 . The results show that the probability of joining a union declines with education, but are not statistically significant. Possession of general training reduces the probability of being a union member. Being a technician and a production work increases the probability of joining a trade union compared to being in the management position. Also the probability of joining a trade union increases as age increases, but only up to a certain age beyond which it starts to decrease.

Tenure significantly increases the probability of joining a union. The picture that emerges is thus fairly clear. Union membership in the manufacturing sector is more important to the workers that have a more vulnerable position in the labour market. The elite of the workers tends to abstain from membership, while the more vulnerable categories tend to join the union. There is also some effect of firm size, namely, that employees in larger and more organised firms, particularly in Nairobi, are more likely to be trade union members.

The last two columns of Table 2 report the marginal effects and $t$-values of the structural form probit model (equation 2). The union premium variable is obtained by taking the difference between predicted earnings from union and non-union earnings (column 2 and 3 of Table 3 ). The union premium is positive and is highly significant. This confirms that union membership choice is positively influenced by earnings differential between union and non-union members. According to the estimation, the probability of joining a union increases by 0.36 percent when the union premium increases by 1 percentage point.

Analogous to the reduced form probit, the signs of estimated coefficient of variables remaining in the structural form probit are similar to those in the reduced form except for previous experience, which is now negative and significant. The secondary and university dummy variables and on-the-job training dummy variable become significant in the structural form 
probit while the general training dummy is now not significant.

Table 2: Probit Estimates for Union Membership choice, marginal effects

\begin{tabular}{|c|c|c|c|c|}
\hline \multirow[b]{2}{*}{ Variables } & \multicolumn{2}{|c|}{ Reduced form Probit } & \multicolumn{2}{|c|}{ Structural form Probit } \\
\hline & Marginal effects & $t$-values & Marginal effects & $t$-values \\
\hline Primary Dummy & -0.0192 & -0.700 & -0.0282 & -1.020 \\
\hline Secondary Dummy & -0.0207 & -0.670 & $-0.0626^{*}$ & -2.000 \\
\hline University Dummy & -0.1079 & -1.340 & $-0.1832 *$ & -2.480 \\
\hline On-the-job training & 0.0319 & 1.310 & $0.0522 *$ & 2.130 \\
\hline General training & $-0.0610^{*}$ & -2.340 & -0.0246 & -0.880 \\
\hline Age & $0.0547^{*}$ & 7.250 & $0.0622 *$ & 8.430 \\
\hline Age Squared & $-0.0007^{*}$ & -7.250 & $-0.0007^{*}$ & -7.070 \\
\hline Male & 0.0142 & 0.490 & 0.0437 & 1.610 \\
\hline Firm size & $0.0002 *$ & 6.380 & $0.0001 *$ & 5.680 \\
\hline Located in Nairobi & $0.1998 *$ & 5.910 & $0.2343 *$ & 6.940 \\
\hline Located in Mombasa & $0.0839 *$ & 1.930 & $0.0847 *$ & 1.970 \\
\hline Located in Nakuru & 0.0713 & 1.570 & 0.0785 & 1.740 \\
\hline Food sector & $0.0930 *$ & 3.400 & $0.1054^{*}$ & 3.380 \\
\hline Wood Sector & $0.0917 *$ & 3.450 & $0.0953 *$ & 3.600 \\
\hline Textile Sector & 0.0304 & 1.190 & -0.0056 & -0.220 \\
\hline Wave 2 & -0.0074 & -0.270 & -0.0290 & -1.120 \\
\hline Wave 3 & -0.0251 & -0.890 & $-0.0944 *$ & -3.320 \\
\hline Previous experience & 0.0024 & 1.170 & $-0.0054^{*}$ & -3.080 \\
\hline Union premium & & & $0.3293^{*}$ & 5.350 \\
\hline Administration dummy & 0.0187 & 0.320 & & \\
\hline Sales dummy & -0.0076 & -0.110 & & \\
\hline Supervisor dummy & 0.0241 & 0.440 & & \\
\hline Technician dummy & $0.1813^{*}$ & 3.200 & & \\
\hline Production work dummy & $0.2546^{*}$ & 5.600 & & \\
\hline Tenure & 0.0128 & 6.110 & & \\
\hline Log likelihood & -1776 & & -1835 & \\
\hline Chi-square & 620.67 & & 334.91 & \\
\hline Significance level & 0.000 & & 0.000 & \\
\hline Pseudo $\mathrm{R}^{2}$ & 0.115 & & 0.086 & \\
\hline Number of observation & 3056 & & 3056 & \\
\hline
\end{tabular}

*significance level $\leq 0.05$

Table 3 shows the results of the estimated earnings equations. The results from the reduced form probit are used to control for sample selection when estimating the earnings functions for union and non-union workers. The second and third columns of the table show the results for union and non-union workers.

As shown in the two columns, all the coefficients on primary, secondary and university education dummy variables are positive, but the primary education dummy is not statistically significant at the 5-percent level. The estimated coefficients increase as the level of education increases. This structure of earnings shows that private average returns to education increase 
with the level of education. The coefficient on general training dummy is positive and statistically significant at the 1- percent level. This coefficient is consistently higher than that of the on-job-training probably due to the fact that firms try to recover the training costs from those who benefit from its training and also at the same time pay more to those with general training to reduce worker turnover. Individuals who work as administrators, sales, supervisors, technicians and production workers receive significantly lower earnings than those who hold management positions. This result is consistent across the two estimated equations. The selection term shows that there is negative selection into unions and positive selection into nonunion. Workers choose to join trade unions partly because of the earning premium as shown by the significance of the coefficient of expected earnings premium in the structural probit model, and partly for other considerations such as job security and better working conditions (Table 1).

Column 4 of Table 3, reports an estimation of the treatment effects model (6). We calculate an F-ratio to test the hypothesis that the earnings equation coefficients are the same for union and non-union workers. The F-statistic $(21,3010)$ is 5.8765 , which is significant at the at the 1 percent level. The hypothesis that the coefficients for union and non-union earnings functions are identical is rejected, suggesting that data for the two sub-samples cannot be pooled.

The two earnings equations for union and non-union sub-samples (Table 3) can be used to compute the union premium. The union premium is obtained by taking the difference between predicted earnings using union and non-union earnings equations reported in columns 2 and 3 of table 3. The average union premium in the sample is about 11.7 percent and is statistically significant at the 1 percent level with a $t$-value of about 18.63. This finding shows that it is important to take into account sample selectivity in estimating the wage effect of union status. It is necessary also to avoid erroneous pooling of data on union and non-union workers when measuring the union premium. If, for example, we were to correct for sample selection, but erroneously pool the data, the union premium would be overestimated, in this case from 11.7 percent to 66 percent (see column 4 Table 3).

Another notable variable in our regression is firm size. It has a positive and statistically significant effect on earnings. This finding shows that those receiving higher earnings benefit 
more by being in large firms than in smaller firms. Tenure has a positive and statistically significant effect on earnings. This shows that workers who have provided longer services to their firms are accordingly rewarded. Working in Nairobi and Mombasa seems to have a statistically significant positive effect on earnings relative to working in other towns. 
Table 3: Earnings Equations - Sample Selection and Treatment Effects Models, Dependent Variable is Natural Logarithm of Hourly Earnings ( $t$-values in parentheses)

\begin{tabular}{|c|c|c|c|}
\hline & \multicolumn{2}{|c|}{ Sample Selection Model } & Treatment effects model \\
\hline Variables & Union Workers & Nonunion Workers & All Workers \\
\hline \multirow[t]{2}{*}{ Constant } & $2.9607 *$ & $2.3236^{*}$ & $2.4972 *$ \\
\hline & $(19.48)$ & $(23.10)$ & $(31.00)$ \\
\hline \multirow[t]{2}{*}{ Primary Dummy } & 0.0351 & 0.0857 & 0.0629 \\
\hline & $(0.950)$ & $(1.920)$ & $(1.920)$ \\
\hline \multirow[t]{2}{*}{ Secondary Dummy } & $0.1030 *$ & $0.2179 *$ & $0.1858 *$ \\
\hline & $(2.465)$ & $(4.533)$ & $(5.190)$ \\
\hline \multirow[t]{2}{*}{ University Dummy } & $0.6621 *$ & $1.0569 *$ & $0.9768^{*}$ \\
\hline & $(4.028)$ & $(9.775)$ & $(10.78)$ \\
\hline \multirow[t]{2}{*}{ On-the-job training } & 0.0135 & $0.0740 *$ & 0.0521 \\
\hline & $(0.382)$ & $(1.979)$ & $(1.820)$ \\
\hline \multirow[t]{2}{*}{ General training } & $0.0835^{*}$ & $0.2383 *$ & $0.2022 *$ \\
\hline & $(1.983)$ & $(6.177)$ & $(6.560)$ \\
\hline \multirow[t]{2}{*}{ Firm size } & $0.0001 *$ & 0.0001 & $0.0001 *$ \\
\hline & $(3.474)$ & $(1.795)$ & $(2.850)$ \\
\hline \multirow[t]{2}{*}{ Administration } & $-0.5009^{*}$ & -0.0731 & $-0.1720 *$ \\
\hline & $(-4.932)$ & $(-0.957)$ & $(-2.270)$ \\
\hline \multirow[t]{2}{*}{ Sales } & $-0.4150 *$ & $-0.4587 *$ & $-0.4671^{*}$ \\
\hline & $(-3.224)$ & $(-5.133)$ & $(-6.210)$ \\
\hline \multirow[t]{2}{*}{ Supervisor } & $-0.5405^{*}$ & -0.1280 & $-0.2415^{*}$ \\
\hline & $(-5.755)$ & $(-1.716)$ & $(-3.940)$ \\
\hline \multirow[t]{2}{*}{ Technician } & $-0.5567^{*}$ & $-0.5811 *$ & $-0.5801 *$ \\
\hline & $(-5.949)$ & $(-7.682)$ & $(-9.400)$ \\
\hline \multirow{2}{*}{ Production } & $-0.7097 *$ & $-0.6850 *$ & $-0.7018 *$ \\
\hline & $(-8.163)$ & $(-10.31)$ & $(-12.70)$ \\
\hline \multirow[t]{2}{*}{ Tenure } & $0.0061 *$ & $0.0105^{*}$ & $0.0084 *$ \\
\hline & $(2.683)$ & $(4.365)$ & $(4.620)$ \\
\hline \multirow[t]{2}{*}{ Located in Nairobi } & $0.3051^{*}$ & $0.3962 *$ & $0.3739 *$ \\
\hline & $(4.836)$ & $(7.980)$ & $(9.210)$ \\
\hline \multirow[t]{2}{*}{ Located in Mombasa } & $0.2009 *$ & $0.1624^{*}$ & $0.1819^{*}$ \\
\hline & $(2.788)$ & $(2.834)$ & $(3.880)$ \\
\hline \multirow[t]{2}{*}{ Located in Nakuru } & -0.0197 & -0.0363 & -0.0303 \\
\hline & $(-0.265)$ & $(-0.597)$ & $(-0.610)$ \\
\hline \multirow[t]{2}{*}{ Food Sector } & $-0.2545^{*}$ & $-0.1750 *$ & $-0.2103 *$ \\
\hline & $(-6.413)$ & $(-4.127)$ & $(-6.520)$ \\
\hline \multirow[t]{2}{*}{ Wood Sector } & $-0.1593^{*}$ & $-0.1010^{*}$ & $-0.1243 *$ \\
\hline & $(-3.971)$ & $(-2.535)$ & $(-4.020)$ \\
\hline \multirow[t]{2}{*}{ Textile Sector } & 0.0629 & 0.0063 & 0.0149 \\
\hline & $(1.650)$ & $(0.162)$ & $(0.500)$ \\
\hline \multirow[t]{2}{*}{ Male } & 0.0619 & $0.1347 *$ & $0.1166^{*}$ \\
\hline & $(1.412)$ & $(3.106)$ & $(3.460)$ \\
\hline Wave 2 & $0.0805^{*}$ & $0.1169 *$ & $0.0968 *$ \\
\hline & $(2.269)$ & $(3.084)$ & $(3.360)$ \\
\hline Wave 3 & $0.5038^{*}$ & $0.3850 *$ & $0.4170 *$ \\
\hline & $(13.32)$ & $(9.579)$ & $(13.66)$ \\
\hline Union Status & & & $0.5071^{*}$ \\
\hline & & & $(8.920)$ \\
\hline Selection term & -0.0855 & $0.4458 *$ & $-0.3632 *$ \\
\hline & $(-1.783)$ & $(12.65)$ & $(-10.97)$ \\
\hline$\sigma_{\mathrm{ui}}$ & 0.441 & 0.652 & 0.591 \\
\hline RSS & 212.39 & 612.51 & 858.72 \\
\hline Number of observation & 1120 & 1936 & 3056 \\
\hline
\end{tabular}

*significance level $\leq 0.05$ 
Tables 4 shows the same model estimation as in Table 3 but restricted to only production workers in the formal manufacturing sector. The estimated coefficients for the education dummies are all positive and are statistically significant except for primary education. The other results are similar to those obtained above except for variations in sizes of estimated coefficients and their levels of significance.

Table 4 : Earnings Equations - Sample Selection and treatment Effects Models for Production Workers, Dependent Variable is Natural Logarithm of Hourly Earnings ( $t$-values in parentheses)

\begin{tabular}{|c|c|c|c|}
\hline & \multicolumn{2}{|c|}{ Sample Selection Model } & \multirow{2}{*}{$\begin{array}{l}\text { Treatment Effects Model } \\
\text { All Workers }\end{array}$} \\
\hline Variables & Union Workers & Nonunion Workers & \\
\hline \multirow[t]{2}{*}{ Constant } & $2.2197^{*}$ & $1.8403^{*}$ & $1.9586^{*}$ \\
\hline & $(16.13)$ & $(18.80)$ & $(28.90)$ \\
\hline \multirow[t]{2}{*}{ Primary Dummy } & 0.0211 & 0.0475 & 0.0393 \\
\hline & $(0.540)$ & $(0.969)$ & $(1.220)$ \\
\hline \multirow[t]{2}{*}{ Secondary Dummy } & 0.0543 & 0.0948 & $0.0883^{*}$ \\
\hline & $(1.315)$ & $(1.690)$ & $(2.370)$ \\
\hline \multirow[t]{2}{*}{ University Dummy } & & $1.0948 *$ & $0.9089^{*}$ \\
\hline & & $(4.975)$ & $(5.090)$ \\
\hline \multirow[t]{2}{*}{ On-the-job training } & -0.0041 & 0.0377 & 0.0259 \\
\hline & $(-0.104)$ & $(0.806)$ & $(0.820)$ \\
\hline \multirow[t]{2}{*}{ General training } & 0.0751 & $0.1851 *$ & $0.1414 *$ \\
\hline & $(1.565)$ & $(3.603)$ & $(3.910)$ \\
\hline \multirow[t]{2}{*}{ Firm size } & $0.0002 *$ & 0.00001 & $0.0002 *$ \\
\hline & $(3.573)$ & $(0.130)$ & $(2.740)$ \\
\hline \multirow[t]{2}{*}{ Tenure } & 0.0042 & 0.0050 & $0.0065^{*}$ \\
\hline & $(1.508)$ & $(1.478)$ & $(2.550)$ \\
\hline \multirow[t]{2}{*}{ Located in Nairobi } & $0.3642 *$ & $0.4128^{*}$ & $0.4282 *$ \\
\hline & $(4.760)$ & $(6.444)$ & $(8.470)$ \\
\hline \multirow[t]{2}{*}{ Located in Mombasa } & $0.2774 *$ & $0.2135^{*}$ & $0.2526^{*}$ \\
\hline & $(3.323)$ & $(3.094)$ & $(4.880)$ \\
\hline \multirow[t]{2}{*}{ Located in Nakuru } & 0.0439 & -0.0325 & 0.0077 \\
\hline & $(0.499)$ & $(-0.443)$ & $(0.140)$ \\
\hline \multirow{2}{*}{ Food Sector } & $-0.2591 *$ & $-0.1398^{*}$ & $-0.1857 *$ \\
\hline & $(-5.876)$ & $(-2.696)$ & $(-5.210)$ \\
\hline \multirow[t]{2}{*}{ Wood Sector } & $-0.1845^{*}$ & -0.0701 & $-0.1151^{*}$ \\
\hline & $(-4.192)$ & $(-1.465)$ & $(-3.440)$ \\
\hline \multirow[t]{2}{*}{ Textile Sector } & -0.0034 & 0.0463 & 0.0271 \\
\hline & $(-0.079)$ & $(0.926)$ & $(0.790)$ \\
\hline \multirow[t]{2}{*}{ Male } & 0.0743 & $0.1211^{*}$ & $0.1068 *$ \\
\hline & $(1.523)$ & $(2.067)$ & $(2.730)$ \\
\hline \multirow[t]{2}{*}{ Wave 2} & 0.0518 & -0.0232 & -0.0033 \\
\hline & $(1.331)$ & $(-0.494)$ & $(-0.110)$ \\
\hline \multirow[t]{2}{*}{ Wave 3} & $0.4578^{*}$ & $0.3208 *$ & $0.3625^{*}$ \\
\hline & $(10.76)$ & $(6.572)$ & $(10.94)$ \\
\hline \multirow[t]{2}{*}{ Union Status } & & & $0.2703 *$ \\
\hline & & & $(2.660)$ \\
\hline \multirow[t]{2}{*}{ Selection term } & -0.0325 & $0.3943 *$ & $-0.1866^{*}$ \\
\hline & $(-0.549)$ & $(6.813)$ & $(-3.051)$ \\
\hline$\sigma_{\mathrm{ui}}$ & 0.418 & 0.607 & 0.514 \\
\hline RSS & 142.05 & 313.14 & 465.24 \\
\hline Number of observation & 815 & 1089 & 1904 \\
\hline
\end{tabular}

*significance level $\leq 0.05$ 
We also calculate an F-test of the hypothesis that the earnings equation coefficients are the same for union and non-union workers using data on production workers only. The F-statistic (16, 1868 ) is 2.5777 , and is significant at the 1 percent level. The hypothesis that the coefficients for union and non-union earnings are identical can be rejected. Thus, as in the previous case, we cannot pool data on union and non-union workers.

The estimated coefficient for union status from the treatment effects model is positive and statistically significant at the 1 percent level. This model suggests that union workers receive 31 percent higher earnings than non-union workers. However, using the union premium, average union premium obtained using the sample for production workers only is again 11.7 percent and is statistically significant with a $t$-value of 16.76 . The 31 percent obtained from the treatment effects model is due to the fact that we erroneously pooled data on union and non-union production workers. The 11.7 percent union premium for production workers is the same as for all workers.

These findings strongly contradict previous earnings effects of unions reported for Kenya (House and Rempel, 1976 and Manda, 1997). Both of these studies found that the effect of unionisation on earnings is negative. We find that the failure to correct for sample selection and endogeneity of the union status is the reason for the negative effect reported in previous studies. Our own estimate of the effect of union membership on earnings without taking account of the endogeneity problem is negative. The conclusion reached by House and Rempel (1976) that the negative effect of unions on earnings is due to substitution between the real wage and other union-provided goods such as job security, employment and fringe benefits is not supported by data, when appropriate estimation methods are used.

\section{Conclusion}

The study has examined the effect of trade unions and other factors such as education, firm size, and tenure on earnings. The results show that earlier results indicating a negative effect of union membership on earnings are due to mis-specification, that is, lack of attention to the endogeneity of the union status of a worker and to sample selectivity problem. When these 
problems are taken into account we get a significantly positive effect of unionism on earnings both in the regression for all workers, and in a more homogeneous group of production workers. The participation equation showed, however, that it is primarily the less advantaged groups that make use of the union. The unions thus primarily benefit the less skilled sections of the labour force, a finding also reported by Schultz and Mwabu (1998) for South Africa.

The union members typically have a relatively larger fraction of their earnings in the form of various allowances. Part of the reasons why trade unions would negotiate higher allowances and benefits for its members is that most of the allowances and benefits have been free from taxation and would therefore entirely benefit the worker. This decision by trade unions to negotiate for higher allowances and benefits is expected, especially in a country like Kenya with one of the highest tax rates on income in the world. Negotiating for higher wages for workers in such a country would easily push the worker into a higher tax bracket and hence considerably reduce their disposable income. In addition, negotiating for higher allowances and benefits for workers would not be quite as involving as it is for higher wages, because employers also stand to gain in terms of tax exemption if they can prove to the government that they actually pay workers the benefits. Thus, negotiating for high allowances and benefits are a better option if trade unions aim to improve the welfare of workers. 


\section{References}

Bigsten, A. (1984), Education and Income Determination in Kenya, Gower, England.

Collier, P. and D. Lal (1986), Labour and Poverty in Kenya 1900-1980, Clarendon Press, Oxford.

Departments of Economics University of Göteborg and University of Nairobi (1994), Limitations and Rewards in Kenya's Manufacturing Sector: A Study of Enterprise Development, World Bank.

Hansen, J. (1997) Essays on Earnings and Labour Supply, $\mathrm{PhD}$ Thesis, University of Gothenburg.

House, W J and H. Rempel (1976) "The Impact of Unionisation on Negotiated Wages in the Manufacturing Sector in Kenya", Oxford Bulletin of Economics and Statistics, Vol. 38.

Ikiara, G. K. and N. S. Ndung'u (1997), "Employment and Labour Market During Adjustments: The case of Kenya," Employment and Training Department, ILO Geneva.

Johnson G. E., (1971) The determination of individual hourly Earnings in Urban Kenya, Discussion Paper No. 115, IDS, Nairobi.

Manda Kulundu, D (1997) Labour Supply, Returns to Education, and the Effect of Firm Size on Wages: The Case of Kenya, PhD Thesis, University of Gothenburg.

Lanfranchi, J. Ohlsson, H. and A, Skalli (2000) "Compensating Wage Differentials and Shift Work Preferences: Evidence From France", University of Gothenburg, mimeo.

Lee, L. F. (1978), "Unionism and Wage Rates: A simultaneous Equation Model with Qualitative and Limited Dependent Variables" International Economic Review, Vol.19, pp. 415-33.

Lubembe, C. K. (1968), The Inside of Labour Movement in Kenya, Equatorial Publishers, Nairobi.

Rempel, H. (1981), “The Labour Market,” In Killick, T. (ed), Papers on Kenyan Economy: Performance, Problems and Policies. Heinemann, Nairobi.

Republic of Kenya (1996), Statistical Abstract. Government Printer, Nairobi.

Sandbrook, R. (1975), Proletarians and African Capitalism: The Kenyan Case, Cambridge University Press, Cambridge.

Singh, M. (1969), History of Kenya's Trade Union Movement to 1952, East African Publishing House, Nairobi. 
Schultz, T. P. And G. Mwabu (1998) "Labour Unions and the Distribution of Wages and Employment in South Africa" Industrial and Labour Relations Review, Vol. 51, No. 4. 


\section{Appendix}

Appendix Table 1: Descriptive Statistics

\begin{tabular}{lcl}
\hline Variables & Mean & Standard Deviation \\
\hline & & \\
Hourly Earnings & 23.515 & 25.138 \\
Hourly Wages (KShs) & 19.338 & 17.024 \\
Primary Dummy & 0.417 & - \\
Secondary Dummy & 0.405 & - \\
University Dummy & 0.028 & - \\
On-the-job training & 0.249 & - \\
General training & 0.175 & - \\
Administration & 0.089 & - \\
Sales & 0.036 & - \\
Supervisor & 0.103 & - \\
Technician & 0.107 & - \\
Production & 0.614 & - \\
Union status & 0.393 & - \\
Firm size (workers) & 159 & 372.54 \\
Tenure (years) & 8.190 & 7.136 \\
Previous experience (years) & 5.386 & 6.460 \\
Age & 34.359 & 8.732 \\
Located in Nairobi & 0.673 & - \\
Located in Mombasa & 0.128 & - \\
Located in Nakuru & 0.100 & - \\
Located in Eldoret & 0.099 & - \\
Food sector & 0.210 & - \\
Wood Sector & 0.247 & - \\
Textile Sector & 0.268 & - \\
Metal sector & 0.274 & - \\
Male & 0.859 & - \\
Wave 2 & 0.307 & - \\
Wave 3 & 0.338 & - \\
Union premium for all workers & 0.305 & 0.211 \\
Union premium for production workers & 0.287 & 0.123 \\
\hline
\end{tabular}

